\title{
Cancer Research Institute
}

\section{Herrick Archives Number 372}

\section{A. IDENTIFICATION \& LOCATION}

1. Name

1.1 Never officially named by Board of Trustees.

1.2 Board minutes refer to this building as "Cancer Institute Hospital" and "Cancer Research Institute."

1.3 Construction drawings generally use two names, "Cancer Research Institute" and "Cancer Radiation Therapy." They also refer to the building as the "Cancer Research Building."

[See Addendum No. 1]

2. Location

2.1 Attached to the east end of Doan Hall (Building 089), between Postle Hall (Building 024) and Starling Loving Hall (Building 176).

2.2 Street address is $300 \mathrm{~W}$. Tenth Avenue. See map below.

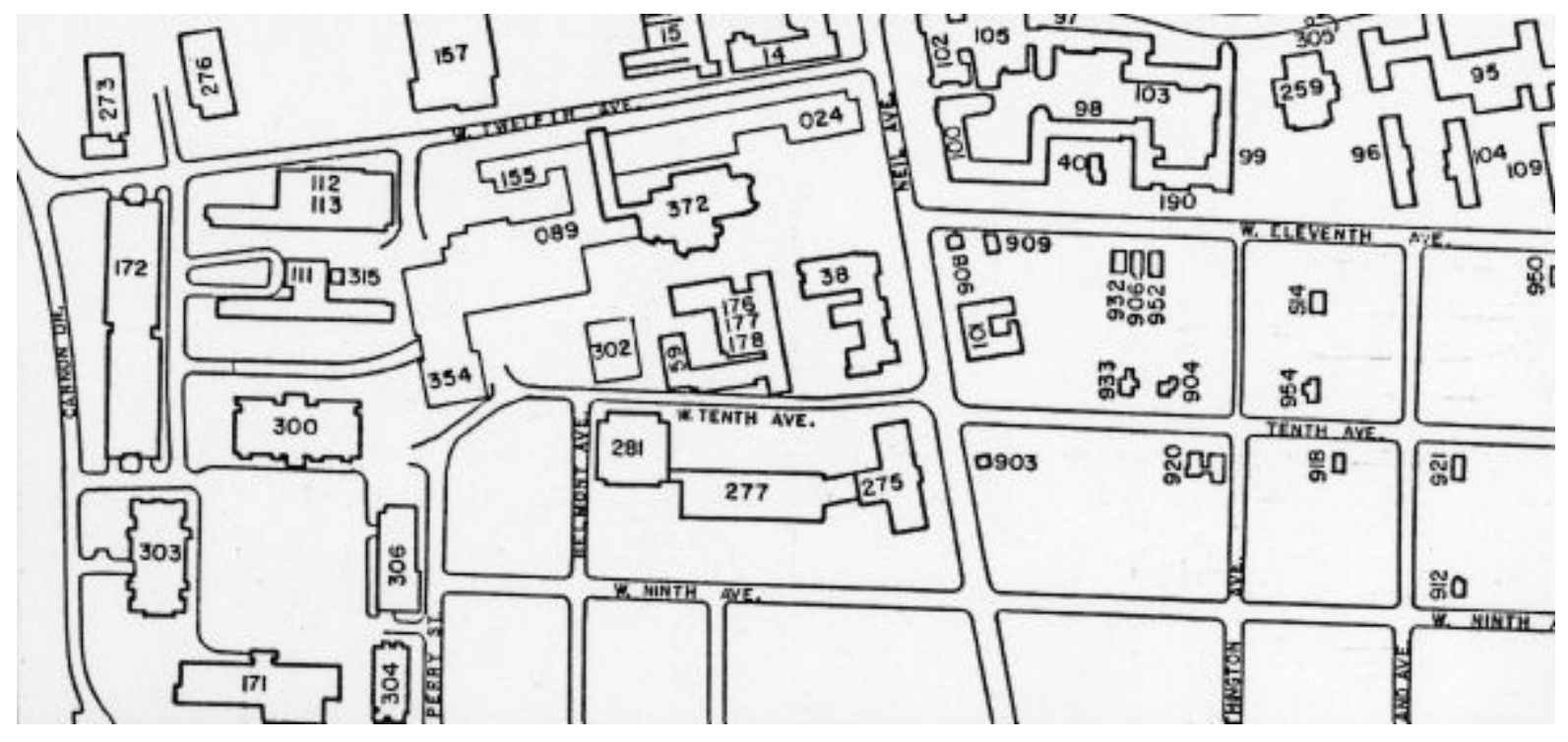

For identification of other buildings shown, see Appendix A.

3. General Description

3.1 Type of construction:

Reinforced concrete frame with brick, limestone, and aluminum exterior.

3.2 No. of stories:

Basement (ground floor) and 12 stories

3.3 Increments of construction: 
No additions; original building still under construction at this time.

\section{B. PLANNING \& CONSTRUCTION}

1. Plans prepared by Bohm/ NBBJ .

2. Site approved by Board of Trustees on October 1, 1982.

3. On December 8, 1983 it was reported to the Board of Trustees that the contract for sanitary sewer relocation required by this project had been awarded to Complete General Construction on the basis of bids received on October 25, 1983.

4. On September 7, 1984 it was reported that contracts for the construction of the building had been awarded (on the basis of bids received on J une 1, 1984) to the following contractors:

General: Massaro Corp.

Plumbing: S.I. Industries

Fire protection: Capital Fire Protection Co.

Heating, ventilating, \& air conditioning: Sauer Mechanical, Inc.

Building Automation: Honeywell, Inc.

Electrical: Meisner Electric, Inc.

5. On September 7, 1984 it was reported to the Board of Trustees that groundbreaking had taken place on J uly 10, 1984 and that completion of the project was anticipated in the spring of 1987.

\section{COST}

The sewer relocation contract awarded in October 1983 was in the amount of $\$ 63,135$; the construction contracts for the building totalled $\$ 31,516,011$, making a total of $\$ 31,570,146$. The total project cost, including contingency allowances, was $\$ 40,451,453$. (Board minutes, December 8,1983 \& September 7, 1984)

J ohn H. Herrick February 26, 1985

\section{ADDENDUM NO. 1}

On October 2, 1987, the Board of Trustees named this building the "Arthur G. J ames Hall." A month later, at its meeting on November 6,1987, the name was changed to "The Arthur G. J ames Cancer Hospital and Research Institute of The Ohio State University." The building is shown in Photographs X30218, X30219, X30220, X30221, X30222, X30245, and X30246 in Photo Archives.

J ohn H. Herrick

J une 2, 1988

\section{ADDENDUM NO. 2}

On December 18, 1989, some sprinkler lines on the top floor of the building were frozen by below zero temperatures. There had been a vent that had been left open and the freezing cold air blew in. The lines froze and broke. This sent 300,000 - 400,000 gallons of water cascading down through all floors of 
the building. The good news was that considering the catastrophe that occurred, very little damage was done to the actual structure of the building. Over the next few months, extensive cleanup and repairs were made and in May of 1990, the hospital was open for use. 